Sarah Bassett

\title{
"Curious Art": Myth, Sculpture, and Christian Response in the World of Late Antiquity
}

Myth, the stories of gods and heroes, stories understood to hover somewhere in the grey area between the white blaze of truth and the black hole of falsehood, was omnipresent in the visual world of the later Roman Empire. ${ }^{1}$ In places public and private; in media as diverse as sculpture and textiles; and in scales ranging from the minute to the monumental, gods and heroes disported themselves with varying degrees of decorum as here a tale of sylvan revelry wove through the border of silken hem, and there a gathering of stately Olympians graced the porticoes of a public space. In its ubiquity myth was unremarkable; except, that is, for the earliest Christian apologists who used it as the centerpiece in their arguments against polytheistic belief and practice. For second- and third-century commentators such as Tatian (c. 120 - c. 180), Athenagoras (c. 133-c. 190), and Tertullian (c. 160 - c. 225), myth, whether encountered through the sounds and cadences of poetry or the shapes and colors of images, took center stage as it encapsulated the error that was Roman belief and practice. Thus, according to Tertullian, who himself looked to the authority of Varro (116-27 B.C.) in structuring his analysis, myth was problematic in that it rooted the understanding of the gods in the quicksands of philosophic argumentation and poetic composition with the former, philosophy, offering only the uncertainty of conjecture, the latter, poetry, mere fable. ${ }^{2}$ Myth was, in other words, an affront to truth. In a like vein Tatian observed that tales of divine metamorphoses, such as that of the aquiline Zeus in pursuit of the comely Ganymede, simply beggared imagination. ${ }^{3}$ As well, the very definition of divinity they offered was suspect, as it showed the immortals caught in the web of human emotions and the impermanence of human experience. ${ }^{4}$

1 Herodotus $(2.23 .1 ; 2.45 .1)$ and Thucydides (1.22.4) define myth as a narrative that is not verifiable. As such it stands in contrast to history. In the fourth century Sallustius, De dis et mundo (On the gods and the world), 3 states unequivocally that myth treats of the divine. On the problems of modern definitions and terminology with respect to the classical world see F. Graf, "Myth" in DNP 9. 444-63. See 452-63 in this same article for an overview of Greek and Roman definitions as they developed between the sixth century B.C. and late antiquity. Graf defines myth as "a traditional narrative of collective significance". This essay layers this basic definition with the ancient understanding of myth as story that is fictitious and implausible. As such it is associated with poetry and seen as distinct from history. See Graf: 445.

2 See generally Tertullian, Ad nationes, 2.1-10. Section 2.1 takes up the tripartite classification of the discussion of the gods set out in Varro's treatise on the divine: their physical nature, which he states is the property of philosophical speculation; their associated myths, the provenance of poetry; and their veneration by different populations. Tertullian argues that the approach is weak as philosophy deals only with speculation and poetry with foolish ideas.

3 Tatian, Oratio ad Graecos, 10 and 26.

4 Tatian, Oratio ad Graecos, 8; Athenagoras, Legatio pro Christianis, 29. 
Worse yet, these stories were unsavory in that they celebrated bad behavior. Those ruffians the gods, rapists, pederasts, and adulterers every one, were a quarrelsome and deceitful lot. Heroes fared no better in their estimation. Consider, for example, Aeneas; a man who abandoned his city and with it his wife before going on to seduce and then jilt Dido. "Must we," quipped an indignant Tertullian, "regard it as a subject of ridicule or indignation that such characters are believed to be gods who are not fit to be men?"5

While these criticisms of myth were applicable to both word and image, images emerged as a discrete target of apologetic vitriol, and among images, one medium, sculpture, bore the brunt of the abuse, for it was sculpture that provoked and nurtured idolatry. The arguments against it were two. To begin with, sculpture demonstrated the falsehood of the gods, the lie of their very existence, and the futility of their worship. Citing the examples the Ephesian Artemis and the Knidian Aphrodite, Athenagoras pointed out that these statues and others of their ilk were mortal inventions, images that were not only conceived of but created by human beings at fixed points in time. Why, he inquires, if the gods truly do exist and are immortal, were their images not present from the beginning? Their images are naught but "earth and stone and matter and curious art." 6 To honor a statue is, therefore, to worship matter, dead material without life or soul, something altogether different from the divine, uncreated and transcendent.

In addition, sculpture provides clear evidence of demons at work in the world. We have the devil to thank not only for bringing us images and with them their artificers, ${ }^{7}$ but also for luring men to their worship. ${ }^{8}$ It is the material essence of sculpture that creates this menace, for, as Athenagoras describes,

When a tender and susceptible soul which has no knowledge or experience of sounder doctrines and is unaccustomed to contemplate truth, and to consider thoughtfully the Father and Maker of all things, gets impressed with false opinions respecting itself, then the demons who hover about matter, greedy of sacrificial odors and the blood of victims, and ever ready to lead men into error avail themselves of these delusive movements of the souls of the multitude, and taking possession of their thoughts, cause to flow into the mind empty visions as if they were coming from the idols and the statues. ${ }^{9}$

5 "Ridendum an irascendum sit, tales deos credi, quales homines esse non debeant?" Tertullian, $A d$ nationes 2.7.7. Trans. P. Holmes in A. Menzies (ed.) Ante-Nicene Fathers (Grand Rapids 1885): 3. 284; Tatian, Oratio ad Graecos, 34 expresses a similar sentiment using more general examples.

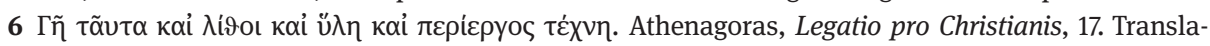
tion: B. P. Pratten in P. Schaff (ed.) Ante-Nicene Fathers (Grand Rapids 1885): 2. 301.

7 Tertullian, De Idololatria, 3.2.

8 Athenagoras, Legatio pro Christianis, 27.

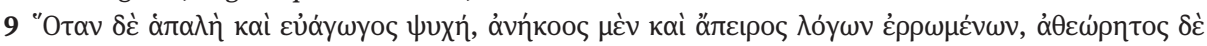

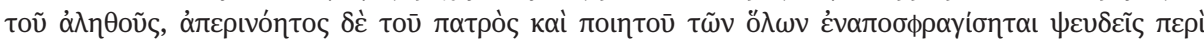

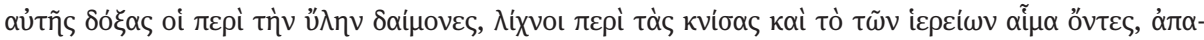

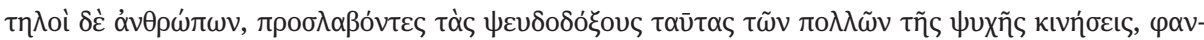

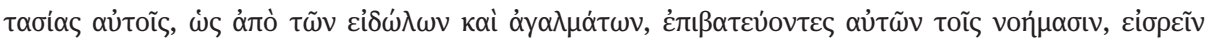

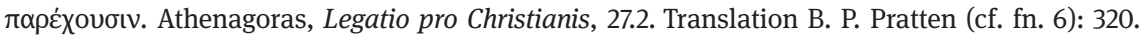


In short, myth and its avatar sculpture were bad business; yet both persisted. Neither the legalization of Christianity at the beginning of the fourth century, nor its ultimate establishment as the religion of state by century's end appears to have diminished their appeal. In cities across the empire statues of gods and heroes maintained their public presence in all manner of civic settings. ${ }^{10}$ Likewise, in the private world of domus and villa, mythological sculpture remained a welcome guest at the dinner table of late antiquity. ${ }^{11}$ Nor was this simply a matter of survival, as new displays, public and private, emerged, some built around sculptured works of antique manufacture, others around works of contemporary production. ${ }^{12}$ Indeed it was only in the sixth century that sculpture well and truly fell from grace, as production slowed and the creation and preservation of installations became less of a concern.

Given the antagonism of the apologists, their certainty that the combined forces of myth and sculpture represented an affront to truth, how was it the case that mythological sculpture remained viable as Christianity became ever more normative a regulating feature of life in the later Roman world? This essay aims to address this apparent contradiction by examining evidence for and response to the use of mythological sculpture in the later Roman world. In so doing it hopes to demonstrate the ways in which the community of Christian faithful, itself ever-expanding and changing over the course of the fourth and fifth centuries as it absorbed new members at all levels of society and moved from outsider to insider status, came to accommodate this great cultural legacy, eschewing the radical stance of the Apologists in exchange for one of acceptance and appreciation that in turn gave way to decline.

Some of the best evidence for understanding the Christian interaction with classical mythological sculpture lies in the material associated with what was arguably the most impressive of all late Roman undertakings, the fourth- and fifth-century development of the city of Constantinople as a new capital for the Roman Empire. Here, in settings public and private, the display of ideal sculpture defied the expectations

10 On urban displays of sculpture see J. Auinger, "The Sculptural Decoration of Ephesian Bath Buildings in Late Antiquity,” in O. Dally and C. Ratté (eds.) Archaeology and the Cities of Asia Minor in Late Antiquity (Ann Arbor 2011): 67-80; M. Aurenhammer and A. Sokolicek, "The Remains of the Centuries. Sculptures and Statue Bases in Late Antique Ephesus: The Evidence of the Upper Agora," in O. Dally and C. Ratté (eds.) Archaeology and the Cities of Asia Minor in Late Antiquity (Ann Arbor 2011): 43-66; F. A. Bauer and C. Witschel (eds.) Statuen in der Spätantike (Wiesbaden 2007); F. A. Bauer, Stadt, Platz und Denkmal in der Spätantike (Mainz 1996); J. J. Pollitt, "The Impact of Greek Art on Rome,” TAPA 108 (1978): 155-74; G. M. A. Hanfmann, From Croesus to Constantine. The Cities of Western Asia Minor and Their Arts in Greek and Roman Times (Ann Arbor 1975), especially 57-74; G. Becatti, “Opere d'arte greca nella Roma di Tiberio," Archeologia Classica 25 (1973): 18-54; D. Strong, "Roman Museums," in D. Strong (ed.) Archaeology in Theory and Practice (New York 1973): $247-64$.

11 On domestic displays of sculpture in late antiquity see L. Stirling, The Learned Collector: Mythological Statuettes and Classical Taste in Late Antique Gaul (Ann Arbor 2005); M. Bergmann, Chiragan, Aphrodisias, Konstantinopel. Zur mythologischen Skulptur der Spätantike (Wiesbaden 1999); D. Brinkerhoff, A Collection of Sculpture in Classical and Early Christian Antioch (New York 1970).

12 Cf. bibliography in fns. 10 and 11. 
of early apologetic commentary. ${ }^{13}$ Representations of gods and heroes crowded the city's fora, streets, and public gathering places. The history of this sculptured population, itself the gift of emperors and high ranking public servants in the period between the foundation of the city in 324 and the death of Theodosius II in 450, indicates both the extent to which displays of statuary remained an essential ingredient in the urban context and the ways in which ideas about and attitudes towards sculpture came to be recalibrated over the course of the fourth and fifth centuries.

Any examination of Constantinopolitan sculptured display must begin with a consideration of the setting. The city, the brain-child of its eponymous founder, Constantine (305-337), stood on the site of the old Greco-Roman town of Byzantium (Fig. 1), a city that had been founded in the seventh century B.C., razed by Septimius Severus (193-211) in the late second century A.D., and then partially rebuilt before being abandoned.

In choosing this site, Constantine launched one of the greatest projects of urban renewal the ancient world had ever known. In the six years between the foundation ceremonies of 324 and the dedication celebrations of 330, new city limits were drawn, old buildings were refurbished, and a monumental armature of colonnaded streets supporting palaces and public gathering places was grafted on to Byzantium's extant plan. The armature's major thoroughfare, the avenue known as the Mese, ran west from the city center, and it was along this scaffolding that the most important Constantinopolitan architectural spaces grew up. In the city center three major complexes coalesced around the Mese's starting point: the forum known as the Augusteion, the Baths of Zeuxippos, and the Hippodrome. Further west, a new space, the Forum of Constantine, circular in shape, straddled the avenue just outside the old city wall. These four complexes stood at the core of the city's Constantinian development. Later in the fourth century at the impetus of Theodosius I (379-395) and members of his dynasty westward expansion continued first with the extension of the Mese and then with the addition of two further fora; the first by Theodosius I, the second by his son and successor Arcadius (395-408). Completion of a new city wall in the early years of the fifth-century reign of Theodosius II (408-450) represented the last major addition to the city's westward push. ${ }^{14}$

13 On the Constantinopolitan collection in particular see most recently S. Bassett, The Urban Image of Late Antique Constantinople (Cambridge 2004) which includes a catalogue of the city's public sculpture and its primary source documentation. Earlier considerations of Constantinopolitan sculpture include C. Mango, “Antique Statuary and the Byzantine Beholder," DOP 17 (1963): 53-75; R. M. Dawkins, “Ancient Statues in Medieval Constantinople,” Folklore 35 (1924): 209-48; G.-C. Heyne, "Priscae artis opera quae Constantinopoli extitisse memorantur," Commentationes Societatis Regiae Scientiarum Gottingensis 11 (1790-91): 209-48.

14 On the development of Constantinople as an imperial capital see Bassett (cf. fn. 13): 17-36; A. Berger, "Streets and Public Spaces in Constantinople," DOP 54 (2000): 161-72; Bauer (cf. fn. 10): 143-268; C. Mango, Le développement urbain de Constantinople (IV ${ }^{\mathrm{e}}-\mathrm{VII}^{\mathrm{e}}$ siècles) (Paris 2004); A. Berger, "Die Altstadt von Byzanz in der vorjustinianischen Zeit," Varia II, Poikila Byzantina 6 (Bonn 1987): 7-30; R. Krautheimer, Three Christian Capitals: Topography and Politics (Berkeley 


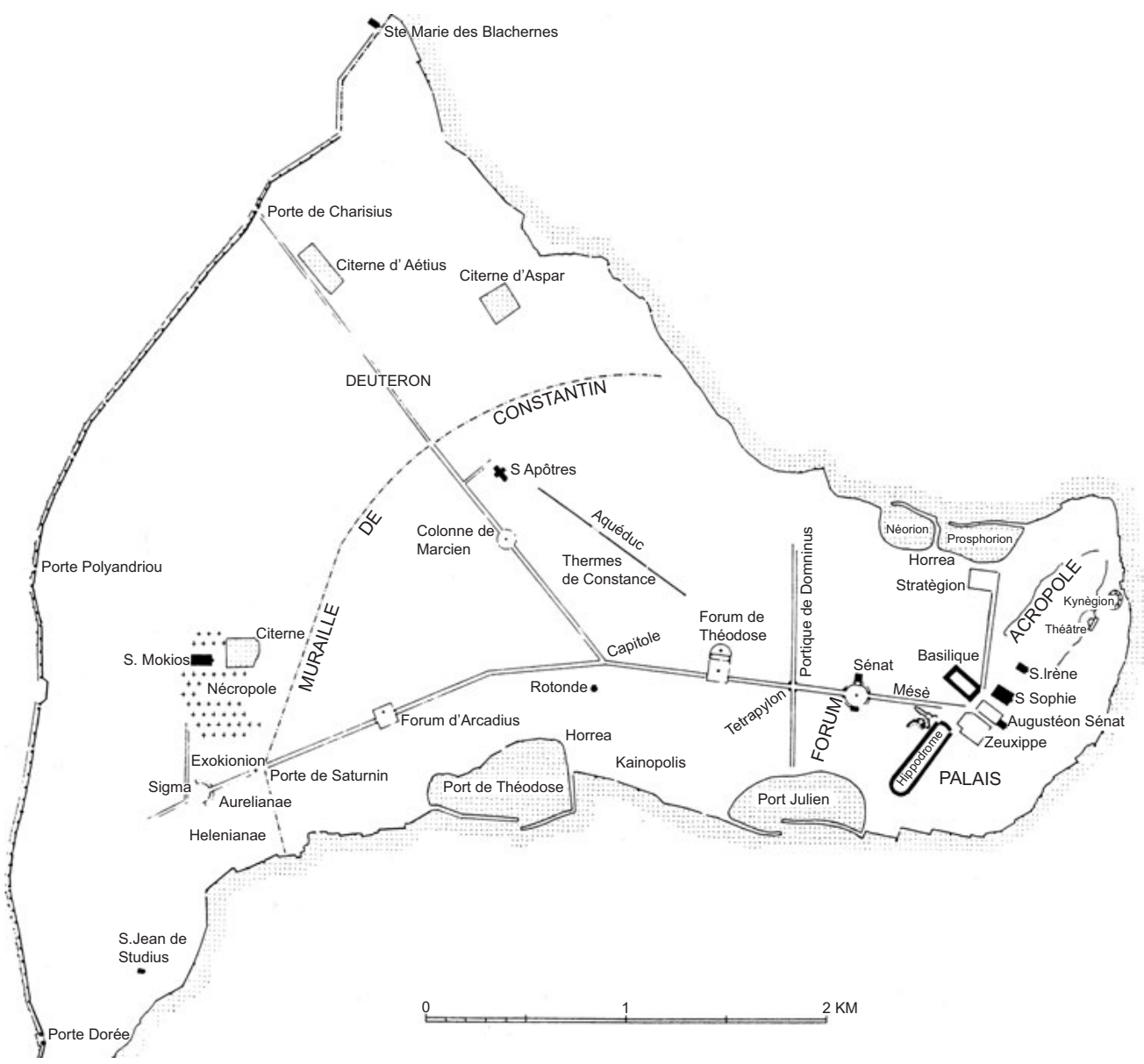

Fig. 1: Plan of Constantinople (after C. Mango, Le développement urbain de Constantinople [IV $-\mathrm{VII}^{\mathrm{e}}$ siècles] [Paris 2004]: Plan II).

Sculptured display was integral to this development from the start. In a manner consistent with traditions in other late Roman cities, these installations included both honorific monuments, the portrait representations of great men and women past and present, and "ideal" or mythic images, the statues of gods and heroes. This sculptured population included works of contemporary manufacture as well as monuments of ancient pedigree brought from the cities and sanctuaries of the an-

1983): 41-68; G. Dagron, Naissance d'une capital: Constantinople et ses institutions de 330 (Paris 1974); H.-G. Beck, “Großstadt-Probleme: Konstantinopel vom 4.-6. Jahrhundert," in H.-G. Beck (ed.) Studien zur Frühgeschichte Konstantinopels (Munich 1973): 1-26; C. DuCange, Historia byzantina duplici commentario illustrata (Paris 1680); P. Gilles (P. Gyllius), De topographia Constantinopoleos et de illius antiquitatibus libri quattuor (Lyon 1561). 
cient world, places such as Rome, Delphi, and Ephesus. ${ }^{15}$ With the exception of a few battered fragments none of this material survives ${ }^{16}$ and it is therefore the evidence of literary sources that allows reconstruction of the public displays implemented under Constantine. $^{17}$

What these sources reveal is a mix of honorific and ideal sculpture in discrete urban settings, with ideal monuments being given pride of place. All told there appear to have been somewhere between 150 and 200 statues in the Constantinian city. Of these around 20 represented Constantine and members of his dynasty, 35 or 40 honored prominent figures from the past, and somewhere between 100 and 110 ranked as mythological sculpture. In terms of manufacture it is likely that the portraits commemorating members of the Constantinian dynasty were for the most part works of contemporary production, while the portraits of historical figures and the mythological sculpture were largely, although perhaps not exclusively,

15 Eusebius, $V C, 3.54$ provides the only contemporary commentary, referring specifically to the sanctuaries of Apollo at Delphi and at Chryse together with the Museion on Mt. Helikon. See Av. Cameron and S. G. Hall (eds. and trans.) Eusebius. Life of Constantine (Oxford 1999): 143. Jerome’s Chronicon provides a global assessment of the emperor's collecting activity in his entry for 324: "Ditatur Constantinopolis paene omnium urbium nuditate quae ante Byzantium dicta." The comment gives a sense of the scope of the enterprise. Shortly thereafter Zosimos, Historia Nova, 2.32 also refers to the global importation of sculpture. See L. Mendelssohn (ed.) Zosimi Historia Nova (Leipzig 1887): 89 -91. Later, and less reliably, Patria Konstantinopoleos 2.73, a $10^{\text {th }}$-century text, lists 25 cities in addition to Rome from which material was alleged to have been taken. See T. Preger (ed.) Scriptores Originum Constantinopolitanarum (Leipzig 1901-07): 189.

16 Material evidence for the late antique city is limited, especially with respect to the imported sculptured materials. Disasters natural and manmade brought about the piecemeal destruction of this collection over the course of the city's long history. Of the antiquities imported to the city in fourth century only a handful survive in the modern city of Istanbul. These include the Obelisk of Theodosius I and the Serpent Column of the Platean Tripod. See Bassett (cf. fn. 13): 219-222 and 224-227 for documentation. Monuments preserved outside Istanbul include a goose recovered from the Hippodrome and the Horses of San Marco in Venice. For the goose see Bassett (cf. fn. 13): 132. For the San Marco horses see Bassett (cf. fn. 13): 222-23. Excavation and recovery of material has been sporadic. Investigations in the 1920s recovered important material pertinent to the Baths of Zeuxippos. See S. Casson, Preliminary report upon the excavations carried out in and near the Hippodrome of Constantinople in 1927 (London 1928); S. Casson, Second report upon the excavations carried out in and near the Hippodrome of Constantinople in 1928 (London 1929); and S. Casson "Les fouilles de l'hippodrome de Constantinople," Gazette des Beaux Arts 30/1 (1930): 215-41. For an overview of more recent archaeological work see C. Barsanti, "Note archaeologiche su Bisanzio Romana,” Milion 2 (1990): 11-50.

17 Roman and Byzantine texts include Christodorus of Thebes, Ekphrasis on the sculpture in the Baths of Zeuxippos ( $5^{\text {th }}$ century) in W. R. Paton (ed. and trans.) The Greek Anthology 1. Loeb Classical Library (London and New York 1916): 58-91; Zosimos (5 ${ }^{\text {th }}$ century) (cf. fn. 15); Chronicon Paschale (7 $7^{\text {th }}$ century) in L. Dindorff (ed.) Chronicon paschale (Bonn 1832); Parastaseis syntomai chronikai ( $8^{\text {th }}$ century) in Av. Cameron and J. Herrin (eds. and trans.) Constantinople in the Eighth Century, the Parastaseis Syntomoi Chronikai (Leiden 1984); Niketas Choniates, De Signis Constantinopoleos $\left(13^{\text {th }}\right.$ century) in J. L. van Dieten (ed.) Niketas Choniates Historia (Berlin 1975): 647-55. 
monuments of ancient - that is pre-fourth-century manufacture - that had been imported from the cities and sanctuaries of the Roman world. ${ }^{18}$

With respect to the mythological, or ideal, sculpture, the most important venues were those of the Baths of Zeuxippos with no less than 48 mythological figures, the Hippodrome with 12, and the Forum of Constantine with ten. ${ }^{19}$ Within each of these settings subject matter appears to have been carefully thought out as each gathering displayed thematic consistency. Thus in the most densely populated of the venues, the Baths of Zeuxippos, two major groups of mythological sculpture emerge: one of gods and demigods associated with water, health, and healing, and another of gods and heroes associated with the epic narratives derived from the Trojan and Theban cycles. The gods and demigods numbered eleven with three statues each of Apollo and Aphrodite, a single figure of Hermaphroditos, and two multi-figured groups, one of Herakles with the nymph Auge and a second showing Poseidon with Amymone. Epic images were linked largely with the Trojan cycle. Among the figures included were those of Achilles, Chryses, and Sarpedon, as well as a series of famous couples attendant at the city's fall: Aeneas and Creusa, Helenos and Andromache,

18 For an overview of sculptured installations in Constantinople see Bauer (cf. fn. 10): 158-66, 17382, 197-202, 209-11, 213-17, 222-24, 227-28, 230-33, 235, 238, 242, 249-54. On the relationship between old and new in sculptured display see: S. Bassett, "Sculpture and the Rhetorical Imagination in Late Antique Constantinople," in O. Dally and C. Ratté (eds.) Archaeology and the Cities of Asia Minor in Late Antiquity (Ann Arbor 2011): 27-41. On ideal sculpture in Constantinople see the catalogue of monuments in Bassett (cf. fn. 13): 143-249. For documentation of the city's late antique honorific portraits see R. Stichel, Die römische Kaiserstatue am Ausgang der Antike (Rome 1982): 76 (no. 7), 83-85 (nos. 47, 52-57), 90 (no. 72), 94-115 (nos. 89-91, 95-101, 105-116, 118-19, 122124, $126-129,131-138,140-44,146)$. For remains of Constantinopolitan honorific sculpture now in Istanbul see N. Firaltı, La sculpture byzantine figurée au Musée archéologique d'Istanbul (Paris 1990): 5-14 (inventory numbers: 1094, 5795, 5028, 73.27, 5077, 5158 A \& B, 4417, 769, 4051, 5673, 5278, 6287, 73.26, 4719). For surviving pieces outside of Turkey see: F. P. Johnson, "The Colossus of Barletta,” AJA 25 (1929): 20 -25; R. Delbrueck, Spätantike Kaiserporträts (Berlin 1933): 217-26; J. Kollwitz, Oströmische Plastik der Theodosianischen Zeit (Berlin 1941): 109-10; S. Sande, "Zur Porträtplastik des sechsten nachchristlichen Jahrhunderts," Acta ad archeologiam et artium historiam pertinentia 6 (1975): 65-106 at 75-76; J. Breckenridge in K. Weitzmann (ed.) Age of Spirituality. Late Antique and Early Christian Art. Third through Seventh Century (New York 1979): 28 - 30; M. Prusac, From Face to Face: Re-Carving of Roman Portraits and the Late-Antique Portrait Arts (Leiden and Boston 2011): 74.

19 On the Zeuxippos see: Bassett (cf. fn. 13): 51-58, 160 - 85 for documentation and commentary; S. Bassett, “'Historiae custos': Sculpture and Tradition in the Baths of Zeuxippos,” AJA 100 (1996): 491-506; R. Stupperich, "Das Statuenprogramm in der Zeuxippos-Thermen. Überlegungen zur Beschreibung der Christodoros von Koptos,” IstMitt 32 (1982): 210 - 35. On the Hippodrome see Bassett (cf. fn. 13): 58-67, 212-32 for documentation and commentary, and S. Bassett, "Antiquities in the Hippodrome of Constantinople,” DOP 45 (1991): 87-96. On the Forum of Constantine see Bassett (cf. fn. 13): 68-71, 188-208 for documentation and commentary. 
Odysseus and Hekube, Kassandra and Ajax, Pyrrhos and Polyxene, and, finally, Oenone and Paris and the reunited Helen and Menelaos. ${ }^{20}$

Nearby, in the Hippodrome, images appropriate to sporting events, victory, and civic identity were the visual currency. Here Herakles struggled through his labors in a series of statues distributed along the circus's central barrier, and there were two monuments of uniquely Roman reference, a Wolf with Romulus and Remus and a Capitoline Goose. ${ }^{21}$

In the Forum of Constantine, where sculpture crowded the rising columnar façade of a nymphaeum, the mythological roster included Paris, Hera, Aphrodite, Athena, Thetis and a group of hippocamps. The particular combination of figures suggests the larger narrative of the wedding of Peleus and Thetis, and within that larger episode the Judgment of Paris. Finally, there was the Palladion, an ancient image of the armed Athena associated first with Troy, then with Rome, before being brought to Constantinople. ${ }^{22}$

What was the purpose of such displays? The only contemporary response comes from Eusebius of Caesarea (263-339) commenting on Constantine's removal of valuables from temples:

\begin{abstract}
In yet other cases the sacred bronze figures, of which the error of the ancients had for a long time been proud, he displayed to all the public in all the squares of the Emperor's city, so that in one place the Pythian was displayed as a contemptible spectacle to the viewers, in another the Sminthian, in the Hippodrome itself the tripods from Delphi, and the Muses of Helicon at the palace. The city named after the Emperor was filled throughout with objects of skilled artwork in bronze dedicated in various provinces. To these under the name of gods those sick with error had for long ages vainly offered innumerable hecatombs and whole burnt sacrifices, but now they at last learnt sense, as the Emperor used these very ones for the laughter and amusement of the spectators. ${ }^{23}$
\end{abstract}

20 For documentation and commentary on the sculpture in the Baths of Zeuxippos see Bassett (cf. fn. 13): $160-85$. For the particular sculpture mentioned here see Bassett (cf. fn. 13): 160 (Achilles, Aeneas and Creusa), 161 (Kassandra), 165 (Andromache), 166 - 68 (Chryse), 170 (Helenos, Helen and Menelaos), 177 (Ajax), 178 (Oenone and Paris), 179 (Odysseus and Hekube), 183 (Pyrhhos and Polyxene), 184 (Sarpedon). Inscribed bases for the support of the Odysseus and Hekube group survive. See Bassett (cf. fn. 13): $180-81$, plates 17 and 18.

21 For documentation and commentary see Bassett (cf. fn. 13): 212-32 for the Hippodrome collection as a whole. For specific works mentioned here see Bassett (cf. fn. 13): 216 (Goose); 218 -19 (individual labors of Herakles); 231 (Wolf with Romulus and Remus).

22 For documentation and commentary see Bassett (cf. fn. 13): 188 (Aphrodite), 188-92 (Athena), 204-205 (Hippocamps and Judgment of Paris), 205-06 (Palladion), 207-08 (Thetis).

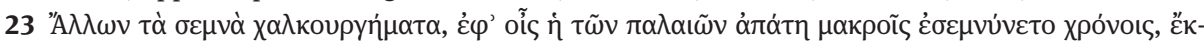

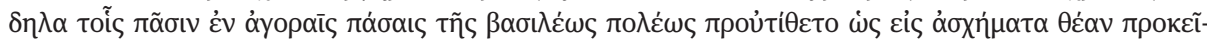

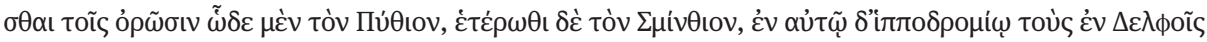

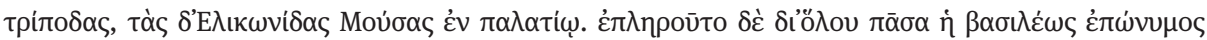

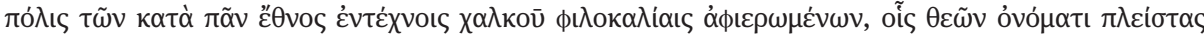

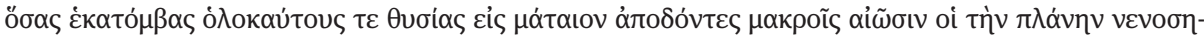


The echo of the apologists resounds through the bishop's observations: for Eusebius, the display of false gods constituted an act of public humiliation.

While it would be imprudent to reject Eusebius's assessment outright, the evidence of the collection itself suggests that there is more at work in this gathering of ideal sculpture than the denigration of pagan images. To begin with, in taking stock of these groupings, it is clear that there is a consistent approach to the display project. Individual collections appear to have conformed to traditional ideas about how sculpture could and should be deployed. Thus, statuary was selected, displayed, and organized around themes appropriate to place. In the Baths of Zeuxippos, the choice of sculpture was consistent with displays seen in the large bathing establishments of Rome and the provincial centers of North Africa and Asia Minor where the presence of gods associated with health and healing and the inclusion of great epic narrative was the norm. ${ }^{24}$ Similar observations may be made about the Hippodrome, which followed the lead of the Circus Maximus at Rome or any one of a number of provincial racetracks in its display of sculpture along the central barrier. That this sculpture included figures such as that of the struggling Herakles was apt: these were the kinds of images that referred both to the struggles of the charioteers who negotiated the course and to the victories that followed. Such images also tended to link themselves to civic identity. Thus, at Tyre, a statue of Herakles, the city's patron god, made a prominent appearance in the circus. ${ }^{25}$ Finally, in the Forum both the presence of a nymphaeum and its adornment with sculpture based on an aquatic narrative is consistent with the locations of and displays in other public fountains at nodal points of civic interaction. ${ }^{26}$

Also important is the fact that these mythic images were not isolated. Instead, they stood throughout the city side by side with works of ancient and contemporary portrait manufacture and other types of public monuments, such as obelisks and honorific columns. ${ }^{27}$ What did this integration of mythic imagery into the city's visual matrix accomplish?

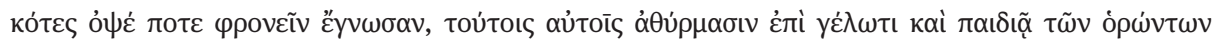

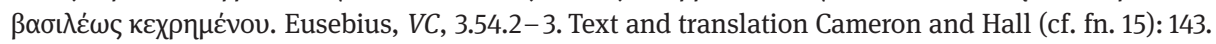
24 Bassett (cf. fn. 13): 53-56. On the sculptured installations of Roman baths see generally H. Manderscheid, Die Skulpturenausstattung der kaiserzeitlichen Thermenanlagen (Berlin 1981).

25 See generally G. Dagron, L'Hippodrome de Constantinople. Jeux, peuple et politique (Paris 2011): 94-107; and Bassett (cf. fn. 13): 58-67. For the specific case of the Herakles at Tyre see J. Humphrey, Roman Circuses (London 1986): 475.

26 On the nymphaeum in the Forum of Constantine see Bassett (cf. fn. 13): 66. For the example of Miletus see Hanfmann (cf. fn. 10): 66-67; G. Kleiner, Ruinen von Milet (Berlin 1968): 114-15; E. Lange, "Die Entwicklungen der antiken Brunnenplastik," JDAI 35 (1920): 100-102; J. Hülsen, Milet V: Das Nymphaeum (Berlin and Leipzig 1919), especially 55-72.

27 For a more thorough discussion of and a suggested approach to understanding the relationship between ancient sculpture and modern, or purpose-made, sculpture in the late antique city see Bassett (cf. fn. 18). 
The iconographic map of the sculptured gatherings, individual and collective, suggests a partial answer. At the Zeuxippos by far the largest number of statues in the display was linked to the Trojan epic, and in a building such as the bath, the kind of space in which civic identity was very much on parade, these mythic images, which were designed in large measure to function on the level of pure entertainment, also worked to describe urban identity. Fifth-century discussion of the foundation of Constantinople by Sozomen (d. 450) makes no secret of the fact that Constantine's first choice of building venue was Ilion, or Troy, rather than Byzantium. ${ }^{28}$ At the root of this interest was the link between Troy and the Roman people. As every schoolboy knew from his labors over the Aeneid, it was the destruction of Troy, the dispersal of its people and gods that brought about the foundation of Rome. Thus, with its emphasis on the moment of the city's fall, the very moment of dispersal, the Trojan myth offered a pre-history of the city, the people, and the empire of Rome that described Constantinople as the heir to this tradition, and as such a New Troy. ${ }^{29}$

Next door, in the Hippodrome, more tales of mythic origin were show-cased with the display of images such as the Wolf with Romulus and Remus. In this instance, the link was, of course, to Rome and its own foundation legend. The image referred not simply to the old capital's foundation myth, but also directly to events that took place in the Constantinopolitan circus, for it was in the Hippodrome that Rome's ancient foundation festival, the Lupercalia, was celebrated. In this ritual reenactment myth sprang to life and Constantinople appropriated the old capital's story for its own, becoming a New Rome. ${ }^{30}$

The theme of a Constantinopolitan connection to the traditions of Troy and Rome came together in the sculptured displays of the Forum of Constantine. The Judgment of Paris group that was part of the larger gathering of figures associated with the wedding of Peleus and Thetis was, of course, the event that set the Trojan epic in motion. And finally there was the Palladion, one of antiquity's great apotropaia. Believed to have fallen to Troy from heaven, it was said to have been kept in the citadel at Ilion as a guarantor of the city's safety. Odysseus and Diomedes carried the statue away, and in their act of rapine created the conditions for the city's fall. According to Roman tradition, Aeneas then rescued the Palladion and brought it to Lavinium, whence it was taken to Rome to act as the city's own defender. There, in the inner sanctum of the Temple of Vesta, it stood as an emblem of the perma-

28 Sozomenos, Historia ecclesiastica, 2.3.2-3.

29 For an extended discussion of the idea of Constantinople as New Troy see Bassett (cf. fn. 13): 7578.

30 On the wolf with the twins see Bassett (cf. fn. 13): 231. For the Lupercalia see Dagron (cf. fn. 25): 67, 72, 82-83, 93, 125-26; Bassett (cf. fn. 13): 64. For an extended discussion of the relationship between Old Rome and New Rome see Bassett (cf. fn. 13): 58-67 and Bassett, “Antiquities” (cf. fn. 19). 
nence of Rome before being brought to Constantinople where its presence testified to the enduring bond between Troy, Rome, and the new capital on the Bosporus. ${ }^{31}$

Troy, Rome, Constantinople: what the sculptured displays in the baths, the circus, and the forum created for the capital was a foundation myth that rooted the city's traditions deep in the soil of the heroic past. That myth and sculpture combined forces to accomplish this task is no accident. In public settings across the Roman world sculptured displays described and documented just such stories. The Constantinopolitan collections were of a piece with this tradition. Further their choice of subject matter reflected the conviction that links to the most ancient antiquity implied in the claim of heroic or divine foundation lent honor and prestige.

Consider for example, the words of the later third-century author, Menander Rhetor, on the writing of urban encomia: "If a city is very ancient you will say that oldest means honorable, and that the city is eternal like the gods." 32 At work in the Constantinopolitan appeal to myth was the desire to grasp that eternity.

That sculpture served as the vehicle for visual delivery is also important. As the great medium of public expression in the cities and sanctuaries of the Roman world, sculpture was the descriptive vehicle that gave life to and documented the history of a place. Accomplishments were commemorated, allegiances expressed, and piety demonstrated with the dedication and maintenance of a vast range of public monuments of which mythic representation was but one aspect. This tradition of public display shaped the image of a city by providing it with visual documentation that not only gave life to claims to importance and prestige, but also, and crucially, enhanced the urban setting and with it civic prestige with the addition of beautiful objects. For it was as much through material essence as iconography that sculpture communicated: sculpture, handsome with the dazzle of rich marble or gleaming bronze, was an index of urban worth in that it gave tangible expression to the value accorded a community by its patrons and benefactors. A city adorned was understood, therefore, as a city steeped in virtue. ${ }^{33}$

A final aspect of Constantinopolitan display was the reused status of the sculpture. With many of the monuments drawn from the cities and sanctuaries of the

31 On the Palladion see Bassett (cf. fn. 13): 205-206. Prokopios, De Bello Gothico, 5.15.10 - 15. H. B. Dewing (ed. and trans.) History of the Wars: The Gothic War, Loeb Classical Library (London and Cambridge, MA 1953-57): 152, and Malalas, Chronographia, 13.8. I. Thurn (ed.) Ioannis Malalae Chronographia (Berlin and New York 2000) offer the earliest and most reliable evidence for the presence of the Palladion (or what was believed to have been the Palladion) in Constantinople.

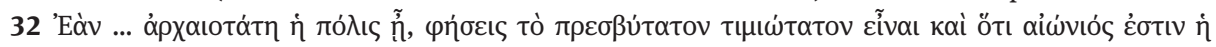

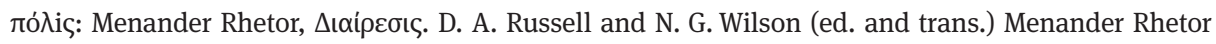
(Oxford 1981): 50-51.

33 That the importation of sculpture to Constantinople were understood as urban adornment is suggested by Socrates (HE 1.16.3) and Sozomenos (HE 2.5.3), both of whom refer to the craftsmanship, beauty, and decorative qualities of the Constantinian sculptured installations. I thank H. Leppin for these references. On ideas about and ideals of civic beauty see H. Saradi, "The kallos of the Byzantine City: The Development of a Rhetorical Topos and Historical Reality,” Gesta 34 (1995): 37-56. 
Roman world, the city found itself a repository of some of the empire's most wellknown sculptured monuments, monuments whose removal to Constantinople from their original settings was an important aspect of their meaning. On a very basic level the installation of sculpture from the far-flung territories of the empire brought the urban wealth of the Roman world to the capital, enhancing the sense of civic virtue. But this wholesale importation of materials also carried with it another connotation. By commandeering such famous monuments as the Wolf with Romulus and Remus, images unique to a particular place, Constantine and his planners claimed not only the wealth of a given city as manifest in the material and craftsmanship associated with sculpture, but also its very soul. To possess a statue like the Capitoline Wolf, an image identified uniquely with Rome, was to lay claim to the identity and power of Rome itself. Indeed, such ownership decreed supremacy. Whether from Rome, Delphi or any one of a number of other cities and sanctuaries, the wholesale in-gathering of the empire's most famous monuments, monuments readily identified with particular places and events, was a way in which to commandeer the history of the empire for the capital and in so doing establish Constantinopolitan hegemony over the cities of the later Roman world. ${ }^{34}$

Pace, Eusebius! Ideal sculpture thrived in Constantinople, not as a subject of ridicule but as a building block of urban identity. With the sculptured installations of the city Constantine and his planners not only visualized a history of mythic origins that gave the place a sense of unrivalled prestige, but also lent the capital an air of beauty expressive of the sense of civic virtue. As this activity indicates, the Constantinian response to classical ideal sculpture was something altogether different from that of the Apologists. Instead of condemning and spurning sculptured tradition, Constantine embraced it as the means to create a compelling image of power.

The Constantinian installations created a backdrop against which the city's ongoing history could unfold, a history that by century's end found expression in public sculpture of a different sort: honorific portraiture. With the accession of Theodosius I in 379 and the subsequent success of his dynasty, the sculptured displays of Constantinople began to focus less on ideal sculpture and more on honorific installations. In fact the number of imperial statues appears to have doubled during the period of Theodosian rule. Thus, sources report approximately 20 statues of Constantine and other members of his family, ${ }^{35}$ a handful of statues representing members of

34 On the issue of appropriation, plunder, and cultural hegemony in the Roman world see most recently I. Östenberg, Staging the World: Spoils, Captives, and Representations in the Roman Triumphal Procession (Oxford 2009). For the specific case of Constantinople see Bassett (cf. fn. 13): 47-49. 35 The numbers are approximate and an exact count is impossible given the overlapping nature of the sources. For images of members of the Constantinian dynasty see Malalas (cf. fn. 31), 13.8; Chron. Pasch. (cf. fn. 17), 528 - 29; John Lydus, Liber de mensibus, ed. R. Wuensch (Stuttgart 1967), 4.138; G. Cedrenus, Compendium historiarum in I. Bekker (ed.) Georgius Cedrenus et Joannis Scylitzae (Bonn 1838-39): 1.564; and the various references in the Parastaseis syntomoi chronikai (cf. fn. 17), 7, 11, 16, 34, 36, 44a, 49, 57, 58, 68. See also C. Mango, The Brazen House (Copenhagen 1954): 46, 48; 
the dynasty of Valentinian I (364-75), ${ }^{36}$ and around 40 statues of Theodosius the Great (379-95) or members of his house. ${ }^{37}$ In part this shift in interest can be explained by the fact that the installations of mythological sculpture engineered under the Constantinian mandate were complete and successful in accomplishing their work. It also reflects the new ruling dynasty's desire to imprint the city with its own dynastic stamp. With the display of portraits of members of the Theodosian house throughout the capital, the city's contemporary rulers integrated themselves into a trajectory of history that began with Troy and continued in Rome, before locating in Constantinople. ${ }^{38}$

Although this focus on dynastic representation altered the nature of public sculptured display, the collection and display of mythological sculpture continued albeit in numbers greatly reduced. In the public arena there is only one notable addition, a statue of Skylla added to the central barrier of the Hippodrome during the reign of Arcadius. ${ }^{39}$ It was instead in unofficial contexts that the most interesting and telling displays of mythological sculpture came into being, probably in the second and third decades of the fifth century. One of these collections, a gathering put together by the court official Lausos in a public portico adjacent to his Constantinopolitan palace, suggests the emergence of a new approach to the question of mythological sculpture, an approach that at first glance appears closer to the condemnatory points of view expressed by Eusebius and his apologetic predecessors, but that emerges upon further consideration as profoundly appreciative of myth and its sculptured tradition.

Who was this Lausos and what was the substance of his collection? Known in an official capacity as grand chamberlain at the court of Theodosius II, Lausos was also the patron of The Lausaic History, a collection of stories by Palladius (c. 364-c. 430) about holy men and women of the Egyptian desert. ${ }^{40}$ This track record makes it clear that Lausos was an interested and influential Christian. It is therefore somewhat surprising to learn that he was also a major collector of the very type of art condemned by Eusebius and the apologists, mythological sculpture. Although his collection was

\footnotetext{
R. Janin, Constantinople byzantine (Paris 1964): 59-62, 73, 62-64; and Bauer (cf. fn. 10): 148, 162, 166, 173, 227.

36 The Parastaseis (cf. fn. 17), 11 notes a statue of Valentinian in the Augusteion without specifying which of the three emperors bearing the name is intended. Similarly, Parastaseis, 12 places a statue of Valentinian at the Modion, or granary. Cameron and Herrin (cf. fn. 17): 199 together with Stichel (cf. fn. 18): 76 (no. 7) suggest identification with Valentianian I, the emperor who established the Modion, against Janin (cf. fn. 35): 66, 69 who favors identification with Valentianian III. Parastaseis, 19 documents equestrian statues of Valentinian I or II at an unidentified location. See also Stichel (cf. fn. 18): 83 (no. 47).

37 See Stichel (cf. fn. 18): 84 (no. 52), 84-87 (nos. 54-57), 90 (no. 72), 94-96 (nos. 89-91), 97-99 (nos. 95-101), 100-101 (nos. 106-12).

38 Bassett (cf. fn. 18).

39 Bassett (cf. fn. 13): 227-30.

40 On Lausos: PLRE 2. 660 -61, s.n. “Lausos.”
} 
destroyed by fire in the latter years of the fifth century, literary sources, the histories of Cedrenus (fl. $11^{\text {th }}$ century) and Zonaras (fl. $12^{\text {th }}$ century), ${ }^{41}$ describe at least thirteen statues on display at the chamberlain's palace: an Athena from the sanctuary at Lindos on Rhodes, a joint project by the sixth-century B.C. sculptors Skyllis and Dipoinos; a Hera from Samos by another early sculptor, Bupalos of Chios; the colossal chryselephantine Zeus by Phidias from the fifth-century temple in the sanctuary at Olympia; Praxiteles's fourth-century Aphrodite of Knidos; two statues by Praxiteles's contemporary Lysippos, an Eros from Myndos and the personification of Kairos, possibly from the sculptor's workshop; and, finally, a series of statues of wild animals and half-human creatures that included tigresses, vultures, giraffes, unicorns, pans, and centaurs, pieces that were likely to have been of Hellenistic or Roman manufacture. ${ }^{42}$

By any index this gathering was extraordinary. Most likely to have been put together during the period of the 420s or the 430s during one of the two periods in which Lausos occupied the post of chamberlain, the collection included seven of the ancient world's most famous temple statues, images often referred to as cult images, ${ }^{43}$ each one the work of an artist of renown; animals real and fantastic of unnamed authorship; and a single personification, a statue of Kairos by Lysippos.

41 Two sources describe the Lausos gathering: two passages in Georgius Cedrenus's Compendium historiarum (cf. fn. 35): 1.564 and 1.616, and a single passage in Zonaras's Epitome historiarum, ed. T. Büttner-Wobst (Bonn 1897): 3.131. On Cedrenus and Zonaras see H. Hunger, Die hochsprachliche profane Literatur der Byzantiner (Munich 1928): 393-94 (Cedrenus) and 416-18 (Zonaras). Because of its chronological remove from the collection, C. Blinkenberg characterized Cedrenus's account of the collection as “ein Gewebe von Fabeln”. See Blinkenberg, Knidia: Beiträge zur Kenntnis der praxitelischen Aphrodite (Copenhagen 1933): 32-34. Others have also challenged the reliability of the texts on the basis of their late date. See T. Stevenson, "What happened to the Zeus of Olympia?," Ancient History Bulletin 21/1-2 (2007): 65-88, especially 65 fn. 2 for references. Stevenson reviews the evidence and eventually agrees with the reliability of the sources. In fact both Cedrenus and Zonaras can be shown to have derived their material from earlier sources, specifically the work of the fifthcentury historian Malchus, thus undermining challenges to their authenticity. For a full analysis of texts and sources see Mango's discussion in C. Mango, E. D. Francis, and M. Vickers “The Palace of Lausus at Constantinople and its Collection of Ancient Statues," Journal of the History of Collections 4 (1992): 89-98 at 89-92. For a catalogue of the individual statues see Bassett (cf. fn. 13): 23238.

42 For the documentation concerning the palace and collection of Lausos see Bassett (cf. fn. 13): 98120 and S. Bassett, “'Excellent Offerings': The Lausos Collection in Constantinople,” Art Bulletin 82 (2000): 6-25. Also important are the contributions of J. Bardill, "The Palace of Lausos and Nearby Monuments in Constantinople: A Topographical Study,” AJA 101 (1997): 67-95; Mango, Francis, Vickers (cf. fn. 41); R. Guilland, Études de topographie de Constantinople byzantine (Berlin 1969): 32; R. Guilland, "Études sur la topographie de Constantinople byzantine: le Palais de Lausos," Helleniki 7 (1962): 95-104; C. M. Bowra, "Palladas and the Converted Olympians,” BZ 53 (1960): 1-7; A. Nagl, “Lausos” in RE, suppl. 7. 365-66; P. Gilles (cf. fn. 14): 129-32.

43 On the problem of nomenclature for sacred temple images see A. Donohue, Xoana and the Origins of Greek Sculpture (Atlanta 1988) and A. Donohue, "Greek Images of the Gods: Considerations of Terminology and Methodology,” Hephaistos 15 (1997): 31- 45 who argues that the concept of the cult 
In its makeup and presentation the Lausos ensemble represented a wholly different approach to myth and sculpture than the massed, interconnected gatherings of ideal statuary that resonated off of one another around the city under Constantine. To begin with, the nature of the sculpture was different. Evidence for statuary associated with the Constantinian collections suggests very strongly that the sculpture, whether used or reused, original or copy, was of a type designed specifically for civic display contexts. By contrast at least half of the sculpture gathered by Lausos came from sacred places, specifically, sanctuaries. Further, typological analysis indicates a preference for standard works of late-classical or Hellenistic manufacture for sculpture in the city's Constantinian displays. Unusually, in the Lausos collection the statues appear to have been unique creations of comparatively early sixth- fifth- or fourth-century B.C. manufacture. Finally, the Constantinian selections narrated a foundation myth that shaped urban identity. There is no hint of such magisterial epic in the Lausos group.

What then to make of such a gathering? If the meticulous documentation of attribution and provenance recorded in the sources is any index, it was the temple statuary that captured contemporary imagination. The focus on individual provenance documents an awareness not only of the origins of the individual images in the great Hellenic sanctuaries, but also cognizance of their geographical distribution. Further, there is a sense of the chronological flowering of individual religious centers. Samos and Lindos were prominent in the seventh and sixth centuries B.C., while Olympia saw its floruit in the fifth and fourth centuries, and Knidos in the fourth. Inclusion of these details suggests an understanding of these images in terms of the religious history and sacred geography of the Hellenic world. ${ }^{44}$

In a like manner, attribution to artist defined the sculpture in terms of artistic chronology by connecting each statue with a discrete historical moment: the Athena and the Hera were made in the sixth century B.C., the Zeus in the fifth, and the Aphrodite and the Eros in the fourth. On display in this chronological unfolding was a history of visual form, a history familiar from such ancient authors as Pliny the Elder (23-79). In fact each of each of the artists represented in the collection holds a place in Pliny's developmental outline of sculptured form. Skyllis, Dipoinos, and Bupalos are recognized as the first sculptors to achieve fame by working in marble, while Phidias is praised for revealing the possibilities of sculpture as a medium, possibilities which were then taken up and elaborated by Praxiteles and perfected by the innovations of Lysippos. Implicit in these observations is the belief in a canon of naturalistic representation and with it a notion of artistic perfectibility. Explicit in the sculpture itself was the range of stylistic experience with the still frontality of Bupa-

image one invented by the early Apologists and is as such inaccurate and misleading. This essay recognizes the importance of her critique, preferring the term 'temple statue'.

44 For an extended consideration of this issue see Bassett (cf. fn. 13): 101-103. 
los's sixth-century Hera standing in marked contrast to the contrapposto poise of Praxiteles's fourth-century Aphrodite or the dazzling torsion of Lysippos's Eros. ${ }^{45}$

Taken together the statues appear to have created a visual epitome both of the history of Hellenic religion and of sculptured form. But how did such epitomes relate to the other major group, that of the animals and mythical creatures? If the detail lavished on the account of the images can be said to have shaped an interpretation of this group within the framework of a human history defined in terms of sacred geography and aesthetic chronology, then the corresponding lack of such description in the catalogue of animals sets these figures outside of that construct. In the absence of provenance or attribution, the animal statues appear to have taken their place within a different order, that of the natural world. The exotic nature of the beasts described and the inclusion of such mythic creatures as pans and centaurs makes clear the nature of this world: this is not the domestic space of the farmyard, but the savage world of the untamed wild. In the Lausos collection these alien, outright barbarous images stood cheek by jowl with some of the most refined and noble creations of the Hellenic past. Comparison must have been inevitable as artifice confronted nature and civilization faced the barbarous.

This visual confrontation suggests the echo of apologetic response to the world of myth and the forms of sculpture. Juxtaposition of great gods with exotic animals and mythical creatures invited comparison between the two groups, a comparison that stressed likeness, ascribing the characteristics of beasts to images of the divine. Like animals these images were without either sense or sensibility. They neither saw, nor heard, nor spoke, nor tasted, nor touched, and they were completely and utterly without soul being only "earth and stone and matter and curious art."46 This was the humiliation of the gods writ large.

It appears, however, to have been only one aspect of the project. The comparison of wild nature with aesthetic artifice was another, one that perhaps worked to suggest new ways of thinking about myth and its images. On the one hand, it is true that the epitome of historical styles summarized in the collection's holdings underscored further the apologist's complaint that images of the gods were but flawed

45 See Plinius, Naturalis Historia, 36.4.9-14 (on Skyllis, Dipoinos and Bupalos); 36.4.15-24 (on Phidias and Praxiteles); 34.19.61-66 (on Lysippos). On Pliny’s idea of art history see J. J. Pollitt, The Ancient View of Greek Art: Criticism, History, and Terminology (New Haven 1974): 73-84. S. Ferri, Plinio il Vecchio, Storia delle arti antiche (Rome 1946); J. Isager, “The Composition of Pliny's Chapters on the History of Art,” Analecta Romana Instituti Danici 6 (1971): 49-62 and J. Isager, Pliny on Art and Society (London 1991). See Bassett (cf. fn. 10):103-105 for an expanded discussion of the idea of artistic perfectibility in late antiquity.

46 Absence of language and a corresponding failure to command the rhetorical structures associated with speech was understood as a hallmark of the primitive and the barbaric. It was, as such, considered a characteristic of foreigners, children, and animals. See Donohue, Xoana (cf. fn. 43): 122-23; R. Sorabji, Animal Minds and Human Morals, the Origins of Western Debate (Ithaca 1993): 7-16, 80 -86. For the range of Roman attitudes towards animals see M. Beagon, Roman Nature (Oxford 1992). 
human creations. On the other hand, with this failing established, that same emphasis on aesthetic chronology proposes an understanding of this sculpture outside of the context of cult. Specifically, it suggests seeing the great works of great artists in place of the great gods of great sanctuaries. In other words, it proposes an understanding of the sculpture in fully aesthetic terms; that is, as art. ${ }^{47}$

That this may be an aspect of the collection's meaning is suggested above all by the presence of the odd statue in the group, Lysippos's personification of kairos. ${ }^{48}$ Defined generally as the "opportune moment", and more specifically in aesthetic terminology as "congruence", the essential element in the creation of beauty, Kairos personified represented neither god nor beast but a mediating figure between the two camps that facilitated contemplation of aesthetic issues by calling attention to the contrast between artifice and nature and the formal history outlined in the sequence of statues. Individually, each statue could be seen to have represented a type of aesthetic congruence. Collectively, the group demonstrated the changing idea of such congruence over time and the mastery on the part of the Greek artists of the imitation of nature. The emphasis on formal issues also had bearing on the animal statues. Untouched by the refining force of congruence, exotic animals and mythical creatures represented nature, the source of artistic invention, in its unperfected state. Kairos thus pulled the raw stuff of animal imagery into league with the perfected artistry of the images by making both statue groups the subject of aesthetic meditation, inviting the contemplation of the relationship at once contradictory and complementary between the natural and the man-made, the imperfect and the perfect object.

If this is the case, then the Lausos collection demonstrated how the gods of Hellenic cult and mythic tradition could be the subject not of religious veneration, but of aesthetic contemplation. In short, it proposed a new way of seeing the sculptured representations of gods and heroes. In this regard it is comparable to other contemporary approaches to the problem of mythological sculpture in general and temple statuary in particular. Contemporary legislation regarding the fate of temples and their images expresses similar sentiments. An edict from the Theodosian Code notes that temple sculptures should be "measured by the value of their art rather than

47 For a fuller consideration of this issue see Bassett (cf. fn. 13): 111-120.

48 Bassett (cf. fn. 13): 108-109. On Lysippos's statue and kairos as an aesthetic phenomenon see A. Stewart, "Lysippan studies I: The Only Creator of Beauty," AJA 82 (1978): 163-71. For further discussion of kairos: A. Corso, Prassitele: fonti epigrafiche e letterarie; vita e opera (Rome 1991): 133; R. Wittkower, "Chance, Time, and Virtue," Journal of the Warburg and Courtauld Institutes 1 (1937-38): 313-21; and two essays by D. Levi, "Il kairos attraverso la letteratura Greca," Rendiconti della Real Accedemia Nazionale dei Lincei: Classe di Scienze Morali Storiche e Filologiche 5th ser. 32 (1923): 260 - 80 and "Il concetto di kairos e la filosofia di Platone," Rendiconti della Real Accademia Nazionale dei Lincei: Classe di Scienze Morali Storiche e Filologiche 5th ser. 33 (1924): 7-117. 
their divinity," ${ }^{49}$ and in a different setting, Prudentius (c. 348 -c. 412) recommended a similar approach to a predominately pagan Roman Senate:

You should give up your childish festivals, your laughable rites, your

shrines unworthy of so great an empire.

Oh noble Romans, wash your marble statues wet with dripping spatters of gore

let these statues, the works of great craftsmen, stand undefiled;

let them become the most beautiful adornments of our native city - may no

depraved purpose taint these works of art, no longer in the service of evil. ${ }^{50}$

"Works of art, no longer in the service of evil": this emphasis on the possibility of aesthetic appreciation reveals both a belief in rehabilitation and with it a desire for preservation which in turn springs from a profound regard for the past and its traditions at odds with apologetic fervor.

Both the poetic exhortations of Prudentius and the terse directives of the law code indicate the extent to which the question of mythological sculpture, that flashpoint for apologetic condemnation, was subject of debate into the later fourth and fifth centuries. But it did so under different conditions. Whereas Tatian, Athenagoras, and Tertullian spoke with the aggrieved voices of outsiders, Prudentius and the authors of the law code did so with the authority of Christian insiders, promoting not destruction, but preservation. In so doing they suggest a new phase of understanding that acknowledged both the discomfort of the Apologists and the value of the traditions of sculptured representation. In short, what these sources suggest is a desire for compromise.

49 "Aedem olim frequentiae dedicatam coetui et iam populo quoque communem, in qua simulacra feruntur posita artis pretio quam divinitate metienda iugiter patere publici consilii auctoritate decernimus neque huic rei obreptivum officere sinimus oraculum. Ut conventu urbis et frequenti coetu videatur, experientia tua omni votorum celebritate servata auctoritate nostri ita patere templum permittat oraculi, ne illic prohibitorum usus sacrificiorum huius occasione aditus permissus esses credatur. Dat. Prid. Kal. Dec. Constantinopoli Antonio et Syagrio conss." Codex Theodosianus 16.10.8 (November $30^{\text {th }}$, 382). Translation C. Pharr, The Theodosian Code and Novels and the Sirmondian Constitiutions (Princeton 1952): 473. For further consideration of the desire to protect pagan patrimony see: J. Alchermes, "Spolia in Roman Cities of the Late Empire: Legislative Rationales and Architectural Reuse,” DOP 48 (1994): 167-78; C. Leppelley, “Le musée des statues divines: la volonté de sauvegarde le patrimoine artistique paeien à l'epoque théodosienne," CahArch 42 (1994): 5-15.

50 "Deponas iam festa velim puerilia, ritus / ridiculos tantoque indigna sacraria regno. / Marmora tabenti respergine tincta lavate, / o procures: liceat statuas consistere puras, / artificum magnorum opera: haec pulcherrima nostrae / ornamenta fiant patriae, nec decolor usus / in vitium versae monumenta coinquinet artis.” Prudentius, Contra Symmachum 1.499-505 in H. J. Thomson (ed.) Prudentius, Volume 1. Loeb Classical Library (London and Cambridge, MA 1953): 388. Translation: Alchermes (cf. fn. 49): 171. 
The Lausos collection appears as a visual manifestation of this stance. Both as act and as argument the Lausos collection challenged the legitimacy of an entire genre of subject, myth, and what was arguably its premier representational medium, sculpture. It was an act to make an apologist proud, for beyond humiliation, this act of collecting, which was at base an act of deracination that removed images from the sacred places that gave them life and meaning, should have presaged the final destruction of pagan cult and with it some of the Roman world's longest lived and most valued cultural traditions. And yet, it did not, at least for the short term. What it proposed instead was a desire to co-exist with and to preserve the past and a means by which to do so: the contemplation of the beautiful.

That such a means of understanding found fertile ground seems to have been the case. To begin with the Lausos collection was not the only gathering of its kind. A contemporary group is known from the Palace of Marina. Marina, daughter of the emperor Arcadius, is reported to have furnished a bath complex in her Constantinopolitan residence with statues of Herakles, river gods, and a relief depicting the battle of the gods and the giants. Although renowned for her piety, a piety expressed in her dedication to virginity and acts of Christian charity, Marina apparently saw no conflict between the claims of Christian devotion and the display of classical sculpture within the confines of her personal apartments. ${ }^{51}$

And of course the great public displays of the city itself give testimony to the fact of their on-going appreciation. Pagan sculpture survived well into the middle ages in Constantinople, the victim not of Christian aggression, but of disasters natural and man-made. From the fourth century on, earthquakes and lightning strikes felled individual statues, while fires took out whole gatherings of sculpture, the Zeuxippos and Lausos collections among them. ${ }^{52}$ The last match was struck in 1204 when the great works of art so central to the city's identity were destroyed or carried away during the sack of Constantinople by the army of the fourth Crusade, a gutting of the urban patrimony that contemporaries took as an occasion for mourning. As Niketas Choniates (c. 1155-c. 1215) makes clear in his great threnody on the city's fall, the destruction of art signaled not only the loss of urban beauty, but also the unraveling of the very fabric of civilization. Niketas's lament reveals the extent to which the aesthetic appreciation of Hellenic tradition had become integral to the Byzantine

51 For documentation see Bassett (cf. fn. 13): 241-242. See also C. Mango, "The Palace of Marina, the Poet Palladas, and the Bath of Leo VI,” in E. Kipraiou (ed.) Euphrosynon: Apheiroma ston Manole Chatzedake (Athens 1991): 1. 321-30; P. Magdalino, "The Bath of Leo the Wise and the Macedonian Renaissance Revisited,” DOP 42 (1988): 97-118; P. Magdalino, “The Bath of Leo the Wise,” in A. Moffat (ed.) Maistor: Classical, Byzantine, and Renaissance Studies for Robert Browning (Canberra 1984): $225-40$.

52 For a chronological list of fires and earthquakes see Janin (cf. fn. 35): 35-36. On fires specifically see A. M. Schneider, "Brände im Konstantinopel," BZ 41 (1941): 382-403. On earthquakes see E. Guidoboni, I terremoti prima del Mille in Italia e nell'area mediterranea (Bologna 1989): 190 -94 and J. Dück, “Die Erdbeben von Konstantinopel,” Die Erdbebenwarte 3 (1903/1904): nr. 6-12. 
mentality. ${ }^{53}$ It was, I suggest, in collections such as the Lausos gathering that this notion first took hold.

From apologetic condemnation to institutionalized acceptance; the shift in attitude that took place between the second century and the fifth represented a sea change in the approach to ideal sculpture. Yet the move from a stance of profound suspicion and animosity to one of cultural accommodation did not represent a steady or controlled tidal swell, as the waves of change broke unevenly over the territories of the Roman world, reflecting the larger process of Christianization itself. ${ }^{54}$ That process, which took hundreds of years to complete, proceeded initially by fits and starts and moved at an uneven pace, engaging the empire's various cultures in different times and places with various rates of success. It was Christianity's encounter with one particular group, the imperial house, which conclusively redirected the conversation. After the Constantinian acceptance of the Christianity, the new religion moved from outsider to insider status and stayed there, save for a brief hiatus during the reign of Julian (360 - 63). With this change in alignment it was only a matter of time before religious and cultural habits began to shift away from the traditions that had shaped Roman behavior for centuries towards a new set of normative cultural practices. That said, the path leading to the establishment of Christianity in the wake of Constantine's profession of faith was neither straightforward nor direct when it came to confronting cultural tradition. Indeed as the fourth-century sculptured installations of Constantinople suggest - installations that were created a full decade after the emperor had proclaimed his allegiance to Christ - there was in no small regard indifference to some of the more pressing concerns of the Christian faithful. Yet, as the comments of Eusebius make clear, the challenge to classical modes of seeing and understanding persisted. It was only, however, by century's end that the burbling undercurrent of suspicion and distrust first voiced by the Apologists swelled to become sufficiently strong a part of mainstream discussion to warrant definitive action, action that was designed not to destroy but to strike a compromise between old and new by finding a neutral ground on which antagonists might meet. The Lausos collection, together with the proclamations of the law code and the appeal of Prudentius, belongs to that moment.

There were no easy answers to the problem of reception, and the urge to find a workable compromise bespeaks the value of myth and its avatar sculpture in late

53 For the text see Niketas Choniates (cf. fn. 17). On Niketas's response to and characterization of the destruction of the Crusader sack see: A. Cutler, "The De Signis of Nicetas Choniates, a Reappraisal," AJA 72 (1968): 113-18.

54 The reception of mythological sculpture in many ways parallels the process of Christianization in the Roman world as laid out in H. Leppin, "Christianisierungen im Römischen Reich. Überlegungen zum Begriff und zur Phasenbildung,” ZAC 16 (2012): 247-78. Leppin proposes a phased model of Christianization in which there appear first various individual Christianities across the territory of the empire. A period of neutralization follows this initial phase. The final phase sees the total dominance of Christianity. 
Roman society. It was, as we have seen, one of the primary means of giving visual life and permanence to the ideas and ideals that percolated in contemporary thought and imagination; ideas and ideals that had been inculcated in every school boy through the study of myth and its agent poetry. The argument about sculpture was therefore an extension of an on-going conversation about the nature and role of intellectual tradition, or paideia, in the face of emerging Christian values, and it is in the context of this larger discussion that the emergence of aesthetic value as a means to facilitate reconciliation can best be understood..$^{55}$

The record of that discussion as it evolved over the course of the fourth and fifth centuries survives at least in part in the works of the Church Fathers. Among the many contributions to the conversation is Basil of Caesarea's (c. 330-379) address to young men on the proper use of Greek literature. ${ }^{56}$ Here at the same time that he acknowledges the perils of Greek poetic tradition - the bawdy stories, the bad exempla against which one should stop one's ears in imitation of Odysseus when faced with the sirens ${ }^{57}$ Basil also is at pains to remind his listeners of the good, pointing out, "all the poetry of Homer is praise of virtue." 58 As his comment suggests, that which is useful is that which reveals and promotes virtue. Basil therefore stresses that the past, its modes of thought and expression, are not without merit, and that it is incumbent upon youth to seek out and be aware of what is useful and apply it to constructive ends. ${ }^{59}$

The address offers no direct advice about art and its reception; nevertheless it is possible to take away two useful directives pertinent to the understanding of things visual from the text. To begin with, properly chosen, it is clear that mythological subject matter, whether in the context of a poem or the visual medium of sculpture, can be edifying. In addition, Basil makes it known that the very process of artistic creation and the marshaling of aesthetic judgment that goes into both the execution and the appreciation of a work of art is itself an exercise in virtue. That this is the case is

55 For the classic study of the paideia see: W. Jaeger, Paideia: Die Formung des griechischen Menschen, 3 vols. (Berlin 1934-47), trans. G. Highet, Paideia: The Ideals of Greek Culture, 3 vols. (New York 1939-44). Ongoing scholarship is rich. Important general studies include P. Brown, Power and Persuasion in Late Antiquity (Madison 1992); R. A. Kaster, Guardians of Language: The Grammarian and Society in Late Antiquity (Berkeley 1988); and H.-I. Marrou, Histoire de l'éducation dans l'antiquité (Paris 1948), trans. G. Lamb, A History of Education in Antiquity (London 1956).

56 For text and translation see Basilius Caesariensis, Прò

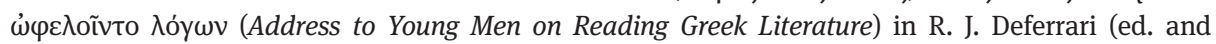
trans.) St. Basil. The Letters, Volume 4. Loeb Classical Library (London and Cambridge, MA 1934): $378-435$.

57 4.2, Deferrari (cf. fn. 56): 388.

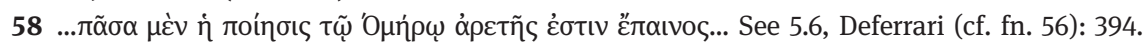

59 The theme of useful and appropriate selection and the equation of usefulness with virtue appears throughout the text, but see especially sections 1.4-5, Deferrari (cf. fn. 56): 380; 4.1-4, Deferrari (cf. fn. 56): 386 - 88; and, finally, 5.12-14, Deferrari (cf. fn. 56): 398 in which Basil recounts the legend of the Choice of Herakles. 
suggested by his remarks on two monumental chryselephantine sculptures, the Zeus by Phidias at Olympia and the Hera by Polykleitos at Argos. In the course of a discussion on the futility of wealth Basil notes that the two artists would have been the laughing stock of their age had they boasted only of the sculptures' materials - gold and ivory - and "overlooked their art." ${ }^{60}$ It was, in other words, art, that is the craftsmanship that allowed the transformation of "earth and stone and matter" into something beautiful and compelling, a visualization of virtue that gave the statues merit.

Basil's exhortation to youth evokes the larger intellectual and emotional environment in which to understand the particular problem of ideal sculpture. It was an environment that recognized the potentially volatile charge of classical culture in Christian contexts and so sought to neutralize it by identifying and emphasizing what it saw as elements of worth and in so doing redirecting function. This context of reconciliation was at far remove from the barbed hostility of the early apologists. Where Tatian, Athenagoras, and Tertullian viewed myth and sculpture in black and white terms as an affront to truth, Basil and his contemporaries, Prudentius and the framers of the law code, saw shades of grey and in them found the potential for virtue. For Basil virtue was expressed in subject matter. For Prudentius and the authors of the code, it was present in the substance and shape of sculpture itself.

The emergence of aesthetic value as a means to understand mythological sculpture was an acknowledgement of the one certain thing that could be salvaged from the images of the gods and heroes, their beauty. It was also a way in which to grapple with the ambivalence surrounding the question of subject matter, for the emphasis on aesthetic value had the effect of neutralizing the religious content of images and in so doing changing their function. Under the new rules sculpture ceased to be a locus of interaction between human and divine, and became an expression of the human potential for virtue because of its ability to embody beauty. As a result the contemplation of beauty, the very visualization of virtue, reflected on the patrons, public and private, who chose sculptured images for display. Whole cities and within them individual patrons expressed their virtue through the possession and display of things beautiful. Beauty as virtue: here was the real congruence, the kairos, between Christian and pagan, past and present, truth and fiction.

In the way of kairos itself, this moment of congruence was short-lived. At the end of the fifth century and the beginning of the sixth fires burning through the center of Constantinople destroyed a substantial amount of the city's population of mythological sculpture, the holdings of the Baths of Zeuxippos and Lausos collections included. ${ }^{61}$ The statuary was never replaced. To a certain extent this was a matter

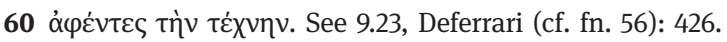

61 Cedrenus (cf. fn. 35) and Zonaras (cf. fn. 41) both report the destruction of the Lausos collection. Cedrenus 1.647 also records the burning of the Baths of Zeuxippos during the Nika riots of 532. Prokopios, De Aedificia, 1.10.3 in H. B. Dewing (ed. and trans.) On Buildings. Loeb Classical Library (London and Cambridge, MA 1940): 83 reports that the baths were repaired by Justinian. A burn layer in 
of practicality: classical mythological sculpture, whether of ancient manufacture or new production, was no longer so readily available. But it was also the case that there was a less of a need for this type of imagery. As the fifth century gave way to the sixth, the issue of Constantinopolitan hegemony began to be seen in new, more fully Christian terms. To this end new types of images based on a new mythology came to the fore, relics associated with the great protagonists of the early Church and their images, or icons. With the importation of the remains of the Apostles Timothy, Luke and Andrew, the proto-martyr Stephen, and those of the forty martyrs of Sebaste, not to mention objects such as the Virgin's cincture or fragments of the True Cross, Constantinople built a new identity on the foundations of the old. ${ }^{62}$ As a complement to its status as New Rome and New Troy, the city was now the New Jerusalem, a place in which urban primacy and the virtue that made such preeminence possible were expressed not through the beauty of mythological sculpture, but in the glory and radiance of Christian remains.

the archaeological record supports the destruction by fire. Reuse of statue bases in the rebuilding strongly suggests that the sculpture was not replaced. See Casson, Second report (cf. fn. 16): 12. 62 The earliest importation of relics to Constantinople was undertaken during the reign of Constantius (337-60) who brought the remains first of Timothy (356) and then of Luke and Andrew (357). Later the Theodosians brought other remains: fragments of the True Cross were deposited in the palace and at the foot of the Column of Constantine, the Virgin's cincture and St. Luke's portrait of Mary with the infant Jesus. Other reported importations, or translations as they are known, included those of the head of John the Baptist (391 and/or 453), Samuel (406), Joseph, son of Jacob (415), Zacharius the father of John the Baptist (415), Stephen, the first martyr (438-39), and those of the 40 martyrs of Sebaste (451). For sources and discussion see C. Mango, "Constantine's Mausoleum and the Translation of Relics,” BZ 83 (1990): 51-62; P. Speck, “The Virgin's Help of Constantinople,” BMGS 27 (2003): 266-71 and the following set of essays by J. Wortley, "Relics and the Great Church," BZ 99 (2006): 631-47; "Relics of the Friends of Jesus at Constantinople," in J. Durand and B. Flusin (eds.) Byzance et les reliques du Christ (Paris 2004): 143-57; "Byzantine Component of the Relic Hoard of Constantinople," GRBS 40 (1999): 353-78; "The Earliest Relic Importations to Constantinople," in Jean-Luc Deuffil (ed.) PECIA: resources en médiévistique (Saint Denis 2005): 207-225; and "The Marian Relics at Constantinople," GRBS 45 (2005): 171-87. 
